\title{
On-Site Traversal Fractional Open Circuit Voltage with Uninterrupted Output Power for Maximal Power Point Tracking of Photovoltaic Systems
}

\author{
Ling Bu ${ }^{1, * \mathbb{D}}$, Shengjiang Quan ${ }^{2}$, Jiarong Han ${ }^{3}$, Feng $\mathrm{Li}^{1}$, Qingzhao Li ${ }^{1} \mathbb{C}$ \\ and Xiaohong Wang ${ }^{4, *}$ \\ 1 School of Information Engineering, China University of Geosciences, Beijing 100083, China; \\ 2104200005@cugb.edu.cn (F.L.); $2104200053 @$ cugb.edu.cn (Q.L.) \\ 2 Department of Mechanical Engineering, The University of Tokyo, Tokyo 113-8656, Japan; \\ quan@g.ecc.u-tokyo.ac.jp \\ 3 School of Automation, Beijing Institute of Technology, Beijing 100081, China; 3220200749@bit.edu.cn \\ 4 Department of Microelectronics and Nanoelectronics, Tsinghua University, Beijing 100084, China \\ * Correspondence: lingbu@cugb.edu.cn (L.B.); wxh-ime@tsinghua.edu.cn (X.W.)
}

Received: 28 September 2020; Accepted: 25 October 2020; Published: 29 October 2020

\begin{abstract}
The fractional open-circuit voltage (FOCV) method is commonly adopted to track maximal power point of photovoltaic systems due to easy implementation and cost-effectiveness. However, the FOCV method is confronted with unstable output power and limited tracking accuracy. This paper proposes a novel on-site traversal FOCV method with uninterrupted output power and increased tracking accuracy through simulation and experimental verifications. Each solar cell is connected with a bypass diode and switching circuitry, so that specific solar cell can be traced and measured consecutively for determining its maximal power point (MPP). MATLAB/Simulink simulation results show that, in the time-varying irradiance case, the proposed method achieves a low ripple factor of $0.13 \%$ in $11-13 \mathrm{~h}$ and $0.88 \%$ in $9-15 \mathrm{~h}$, under the typical $24 \mathrm{~h}$ irradiance curve. In the spatial-varying irradiance case, the accuracy of the proposed method reaches $99.85 \%$. Compared with other FOCV methods, like pilot cell and semi pilot cell methods, the proposed method is of higher accuracy with a limited ripple effect. Experimental results show that this method can effectively trace different output performance of specific solar cell while generating stable output voltage with a low ripple factor of $1.55 \%$, proving its compatibility with distributed sensing and applicability in smart photovoltaic systems.
\end{abstract}

Keywords: fractional open-circuit voltage; on-site; uninterrupted output power; maximal power point tracking

\section{Introduction}

The ever-declining petroleum resources have forced worldwide nations to optimize the energy mix for sustainable development. In the global search for clean, renewable and safe energy sources, solar power is most concerned due to its ubiquitous existence, inexhaustible amount, and high-level safety. The past decade has witnessed tremendous growth in the global photovoltaic market, and this trend is still continuing. At the end of 2019, the world's total photovoltaic capacity has reached 580 GW, which is increased by $20.1 \%$ compared with 2018 [1]. In China, it is expected that the cumulative installed photovoltaic capacity will be rocketed from $130 \mathrm{GW}$ by 2017 [2] to approximately 2.7 TW by 2050 [3].

Despite the fast growth rate, photovoltaic systems are still confronted with the challenge of enhancing efficiency. Solar cells typically exhibit nonlinear power-voltage curves [4], and are very 
sensitive to external conditions [5]. Given the invariably changing irradiance and temperature, it is crucial to keep all solar cells generating at maximal power point (MPP) so as to enhance the conversion efficiency of photovoltaic systems. To this end, various maximal power point tracking (MPPT) techniques have been presented, displaying different features including accuracy, tracking speed, algorithm complexity, steady-state oscillation, hardware installation, and cost [6-11].

Direct methods such as Perturb and Observe $(\mathrm{P} \& \mathrm{O})$ and Incremental Conductance $(\mathrm{InC})$ have been proposed to directly calculate the MPP. In the P\&O method, the control unit will slightly increase or decrease the output voltage, measuring and comparing output power until MPP is reached. The InC method calculates MPP by comparing incremental conductance and module conductance. Both methods offer good extendibility to different scales of photovoltaic systems, but are of limited dynamic response and is susceptible to oscillation around the MPP [12]. In both methods, the perturbation step size is a key parameter, as a small step size lowers tracking speed but a large step size reduces tracking accuracy [13]. As a trade-off, the variable step size has been presented. For instance, a two-stage algorithm is incorporated into the $\mathrm{P} \& \mathrm{O}$ method to achieve coarse tracking in the first stage and fine tracking in the second stage to reduce response time [14]. In a variable step size InC method, direct control of the scaling factor is proposed to increase the speed of convergence while maintaining tracking accuracy [15]. However, the steady-state oscillation problem is still not completely excluded. Moreover, under asymmetrical conditions such as hot-spotting or partial shading, both methods cannot guarantee effective tracking of global MPP [16].

Recently, a variety of algorithm-based MPPT methods (a.k.a. soft MPPT methods) have been presented, including artificial neural networks (ANN) [17-21], fuzzy logic (FL) [22-24], grey wolf [25], artificial bee colony [26], particle swarm optimization (PSO) [27-30], etc. These methods provide robust and versatile performance, and are generally capable of tracking global MPP under various conditions. For ANN methods, MPP voltage is accurately calculated through improved network architecture such as back-prorogation network [17] and radial basis function network [18], or through optimization algorithms such as genetic algorithm [19] and gradient descent momentum algorithm [20]. By incorporating the auto-scaling method into the FL controller, fast transient tracking speed and good convergence around MPP are jointly achieved [22]. Based on a PSO algorithm featured by reducing swarm size, global MPP has been tracked with fast convergence speed under partial shading conditions [27]. However, these methods usually require complex mathematical models and calculations, and the effectiveness of these methods usually relies on careful selection of model parameters or massive data training in advance. For instance, the ANN MPPT adopted in [21] registered training with data obtained in one year. The membership function in FL MPPT also requires sufficient experiments and modifications to be built properly [23]. Upon a sharp change of photovoltaic system characteristics or ambient conditions, these methods also require more time to learn and to adapt [31].

On the contrary, fractional open-circuit voltage (FOCV) is a widely adopted MPPT method in practice due to its low calculation complexity, easy implementation and cost-effectiveness [32-34]. Though it tracks MPP in an indirect way, it has fast-tracking speed and minimal requirements of sensors, and is of comparable accuracy in most situations [35]. The main problem of the FOCV method is the disturbed output power due to the common practice of disconnecting PV panel from the load during open-circuit voltage measurement. This measuring period not only results in temporal loss of power, but also affects the accuracy of tracked MPP. To solve this problem, methods such as pilot cell [36] and semi pilot cell [37] have been proposed, in which pilot cells are used for measuring open-circuit voltage. For these two methods, the representativeness of the pilot cells is a big issue, esp. in non-uniform insolation conditions. In addition, the semi pilot cell method results in increased ripple of output power. In order to realize interruption-free output power, an online FOCV method has been proposed [38]. The open-circuit voltage is calculated through a model based on the results of multiple sensors, including current, voltage and temperature, which increases complexity in both calculation and hardware implementation. 
In this paper, we present an improved traversal FOCV method with easy implementation and uninterrupted output power. The open-circuit voltage of each solar cell is measured on-site through consecutively switching in or out, solving the representativeness issue. Meanwhile, the output power is not disturbed as the number of power generating cells remains constant. The proposed method will be explained in detail in the following sections, and will be compared with the pilot cell and semi pilot cell methods in both time-varying irradiance and spatial-varying irradiance conditions.

\section{Proposed Method}

The traditional fractional open-circuit voltage method is based on the approximation that the MPP voltage has a linear relationship with open-circuit voltage. The whole panel is connected with the load in the powering session, and is disconnected from the load in the tracking session to measure open-circuit voltage and estimate MPP of the whole panel. This method has two problems: (1) MPP is estimated for the whole panel rather than specific solar cells; (2) during the tracking session the power loss is $100 \%$ and fluctuations are inevitable.

One improving method is the pilot cell (PC) method, in which an individual pilot cell is set aside on the photovoltaic panel, as is shown in Figure 1a. The pilot cell can be tested periodically or continuously, while the remaining solar cells generate power to the load. It avoids power loss of the whole photovoltaic panel while open-circuit voltage measurement is in process. However, the problem still exists in that electrical characteristics of the pilot cell may not be representative of all solar cells in the system, and thus the calculated MPP might not be accurate for the entire photovoltaic panel.

Another improving method is the semi pilot cell (SPC) method. As is shown in Figure 1b, a selected semi-pilot cell is either connected with an antiparallel bypass diode (Path (1) to generate power with other solar cells on the panel, or connected with a voltage sensor (Path (2) for open-circuit voltage measurement. In the latter condition, the bypass diode turns on to maintain the current on the panel. The semi-pilot cell method increases output power for small-scale photovoltaic systems, but the changing amount of generating solar cells increases the fluctuation of generated power. Still, the measured open-circuit voltage of the chosen semi-pilot cell is not representative of all solar cells in the photovoltaic panel.

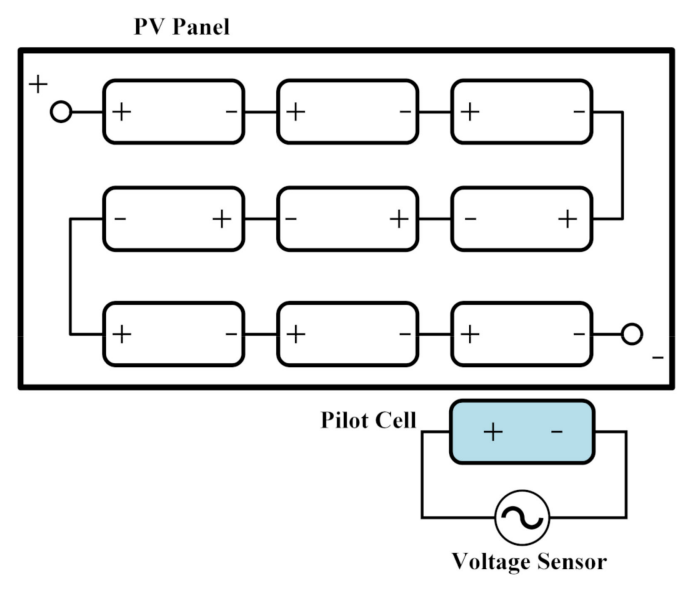

(a) Pilot Cell Method

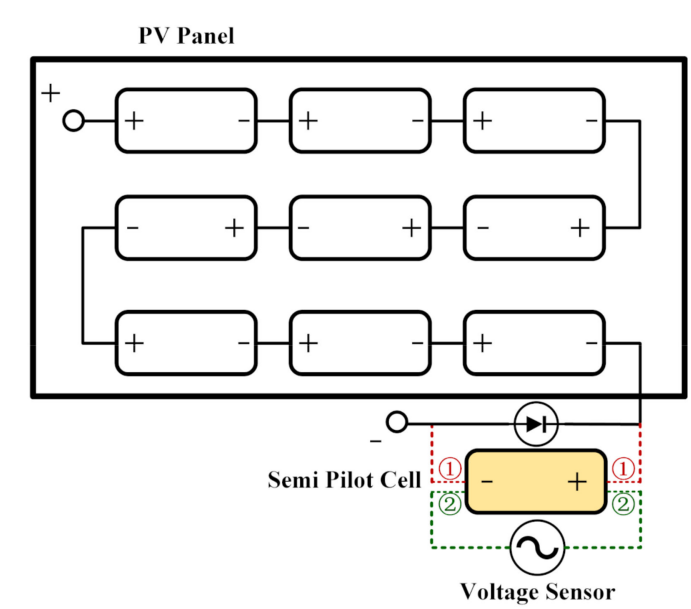

(b) Semi Pilot Cell Method

Figure 1. Schematics of the conventional fractional open-circuit voltage (FOCV) methods: (a) pilot cell (PC) method and (b) semi pilot cell (SPC) method.

The presented on-site traversal fractional open-circuit voltage method is shown in Figure 2. Each solar cell was connected with a bypass diode and a couple of reverse single pole double throws (SPDTs). Here, Schottky diodes were selected as bypass diodes for their low forward voltage drop 
and high switch frequency, which was suitable for the fast switching in and out in the proposed method. In the SPDTs, Point 1 was connected with the specific solar cell. Point 2 was connected with other cells in the panel in series. Point 3 was connected with the voltage sensor. Only one voltage sensor was needed in the proposed method, as it was shunt with Point 3 of all SPDTs. Assuming that the total amount of solar cells is $\mathrm{N}$ in the photovoltaic system, the proposed method operates as follows:

(1) The mth solar cell $(\mathrm{m}=1,2, \ldots, \mathrm{N}-1)$ is connected with voltage sensor through Point 3 for open-circuit voltage measurement, while all other $\mathrm{N}-1$ solar cells are connected to load through Point 2 and are generating power.

(2) SPDTs of the mth solar cell and the $(m+1)$ th solar cell changes simultaneously. For the $m$ th solar cell, SPDTs switch from Point 3 to Point 2 . For the $(m+1)$ th solar cell, SPDTs switch from Point 2 to Point 3.

(3) After the switch change in (2), the mth solar cell is connected to the panel for power generation, while the $(m+1)$ th solar cell is connected with voltage sensor for open-circuit voltage measuring.

(4) This process proceeds as all solar cells in the panel are measured in the traversal.

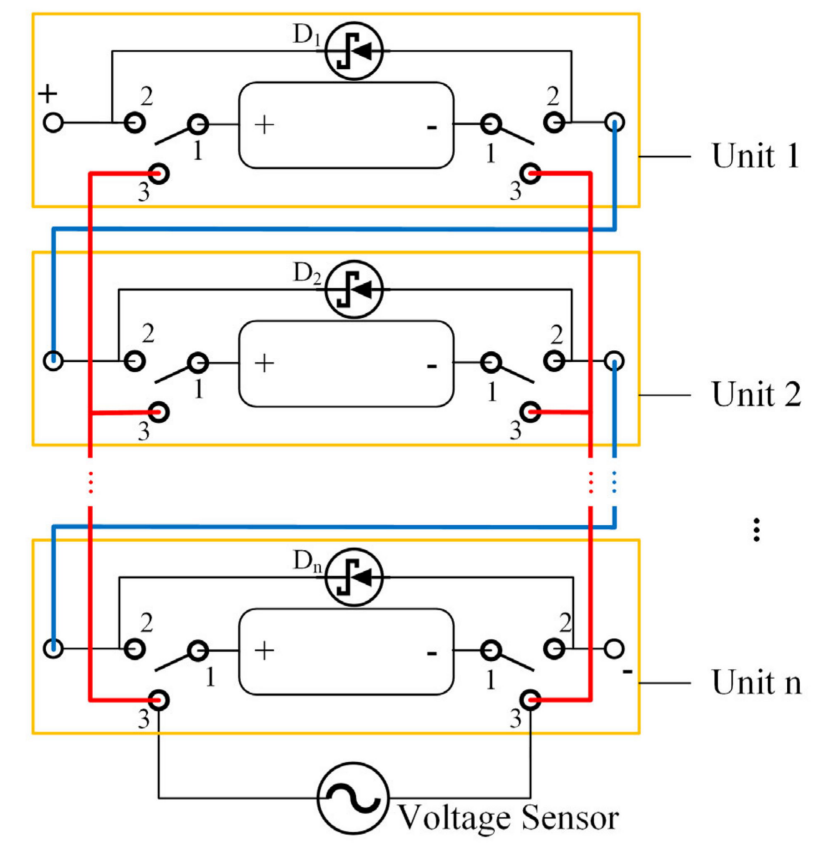

Figure 2. Proposed on-site traversal FOCV maximal power point tracking (MPPT) technique.

In the proposed method, every independent solar cell owns its non-overlapping measurement window phase with equal time length $\Delta t$. The operation cycle $T$ of the entire system is:

$$
T=N \Delta t
$$

For simplicity, assume that the output voltage of a single cell is $u_{0}(t)$. Throughout the entire cycle $\mathrm{T}$, the output voltage of the panel to the load $u_{\text {out }}(t)$ is:

$$
u_{\text {out }}(t)=(N-1) u_{0}(t) .
$$

It can be seen from Equation (2) that, constant number of generating solar cells is the key to reduced ripple and stable output. The fast switching speed of power electronics enables real-time measurement for the open-circuit voltage of each solar cell, and since the measurement is performed on-site rather than representatively, the obtained MPP of the whole panel is more accurate compared with the PC method or SPC method. 
For large scale photovoltaic systems, the principle of the proposed method can also be extended to implement on a solar panel scale. In this circumstance, each panel serves as an independent unit for measuring open-circuit voltage and determining local MPP. Compared with solar cell scale implementation, which usually requires on-chip integrated electronics, processing and control on the solar panel scale can be achieved via circuit boards, which offers more flexibility and better compatibility for existing systems.

Regardless of cell scale or panel scale implementation, the proposed method provides the feasibility that all units can be specifically controlled using SPDTs. Based on this, the measuring sequence can be further extended as sequential, random, or depending on the task. Such a feature is especially helpful when combined with distributed sensing of environmental conditions, e.g., when a hot spot or shaded spot has been sensed, the location-specific solar cell/panel can be instantly on-site measured to adjust the MPP of the whole system.

\section{Modeling of Solar Cells}

The practical solar cell is usually modeled as an ideal solar cell with parallel and serial resistances. As is shown in Figure 3, $I_{p h}$ is the ideal current source, $D_{1}$ is the inherent diode, $R_{p}$ represents leakage current, and $R_{s}$ represents the internal power loss due to current flow.

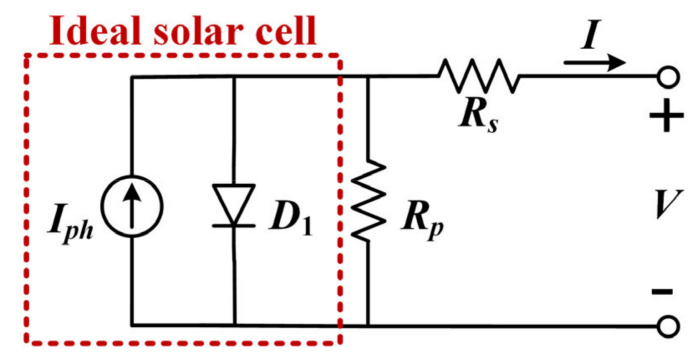

Figure 3. Equivalent model of the solar cell.

The $I-V$ relation of Figure 3 is described as:

$$
I=I_{p h}-I_{s}\left[e^{\frac{V+I R_{s}}{N V_{t}}}-1\right]-\frac{V+I R_{s}}{R_{p}}
$$

where $I$ is the output current of the solar cell, $V_{t}$ is the thermal voltage of the diode and is equal to $k T / q$, in which $k$ is the Boltzmann constant, $q$ is the electron charge, and $T$ is the junction temperature in Kelvin. $I_{S}$ is the diode reverse saturation current, $N$ is the quality factor of the diode, and $V$ is the output voltage of the solar cell.

Assuming that $R_{p}$ is infinite and $R_{S}=0$, Equation (3) can be simplified as:

$$
I=I_{p h}-I_{s}\left[e^{\frac{V}{N V_{t}}}-1\right]
$$

In open-circuit condition $I=0$, so Equation (4) can be rewritten as:

$$
N V_{t}=\frac{V_{o c}}{\ln \left(\frac{I_{p h}}{I_{s}}+1\right)},
$$

where $V_{o c}$ is the open-circuit voltage of the solar cell.

Denoting $\gamma$ as the ratio between $I_{p h}$ and $I_{s}$ :

$$
\gamma=\frac{I_{p h}}{I_{s}} .
$$


Output current I can be obtained from Equations (3), (5) and (6):

$$
I=I_{p h} \cdot\left[1-\frac{1}{\gamma}(\gamma+1)^{\frac{V}{O O C}}+\frac{1}{\gamma}\right] .
$$

Since $\gamma>>1$, the general trend depicted in Equation (7) is that $I$ decreases as $V$ increases. Maximally when $V=V_{o c}$, the output current $I$ is zero.

The output performance of solar cells is simulated using MATLAB/Simulink, and the testing circuit is shown in Figure 4. The circuit consists of ten solar cells in series whose input irradiance $I_{r}$ is given by a constant irradiance $C$. The parameters of the solar cells are: $V_{o c}=0.6 \mathrm{~V}, I_{s c}=6 \mathrm{~A}$. The load resistance is increasing with time from 0 to a finite value to collect data from short-circuit status to almost open-circuit status. Solar irradiance is set as 1000, 800, 600, 400 and $200 \mathrm{~W} / \mathrm{m}^{2}$, and ambient temperature is set as 0,25 , and $50{ }^{\circ} \mathrm{C}$, respectively.

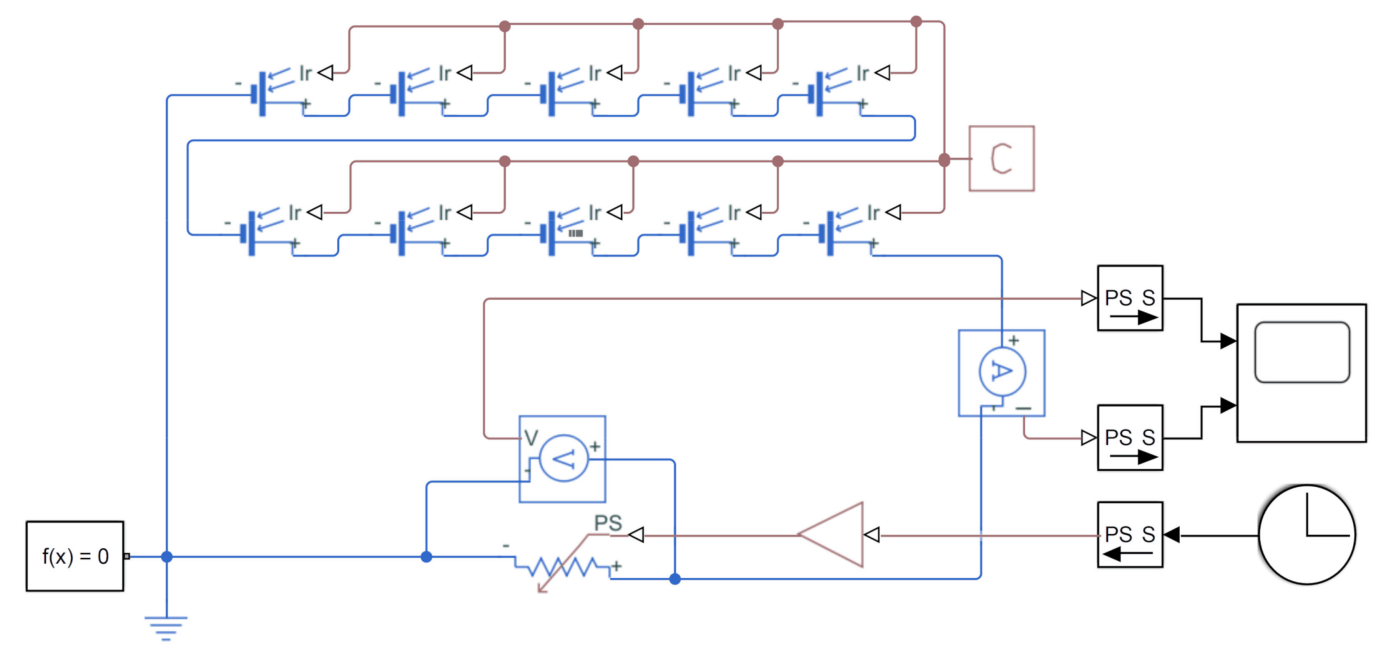

Figure 4. Simulation circuit for the measurement of characteristics of solar cells.

The simulated $P-V$ curves of the solar cells under different irradiations and temperatures are shown in Figure 5. For Figure 5a, the temperature was set to $25^{\circ} \mathrm{C}$, while for Figure $5 \mathrm{~b}$, the irradiance was set as $1000 \mathrm{~W} / \mathrm{m}^{2}$. It can be seen clearly that MPP drifts with irradiations and temperatures. The output power increased with increasing solar irradiance but decreased with increasing temperature. Since output power changed more conspicuously under different light irradiance than under different temperatures, the following simulation works were majorly focused on different light irradiance.
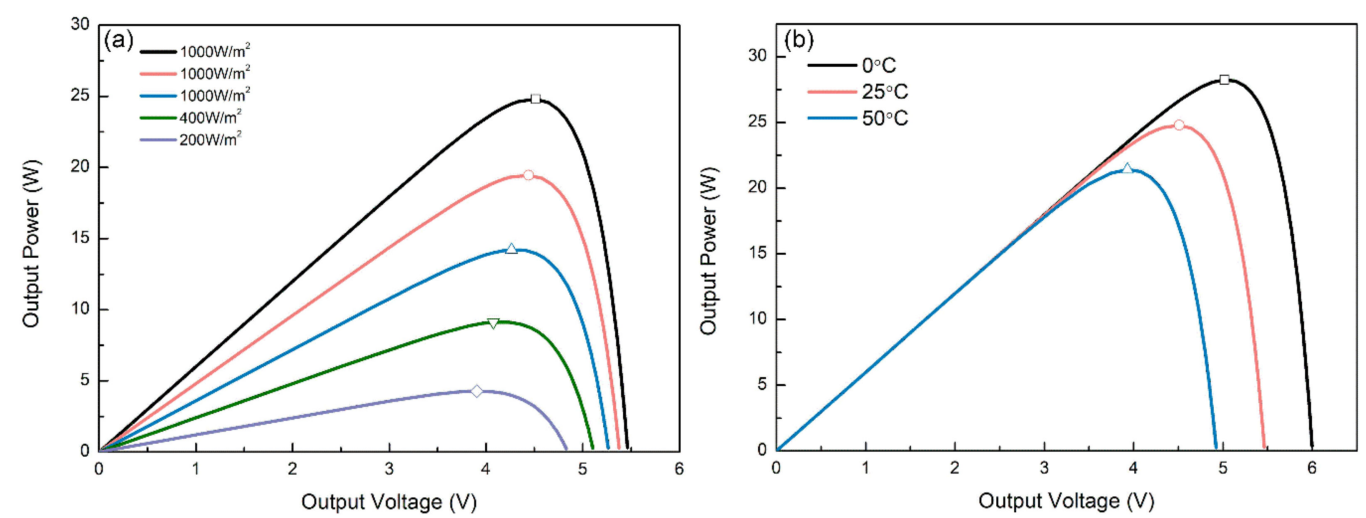

Figure 5. The output performance of solar cells: (a) $P-V$ curves under different solar irradiance; (b) $P-V$ curves under different ambient temperatures. 
In a photovoltaic system, the MPP voltage $V_{m p p}$ of the solar cell keeps an approximately linear relationship to its open-circuit voltage $V_{o c}$ :

$$
V_{m p p} \approx k \cdot V_{o c}
$$

where $k$ is a proportionality factor, and is mainly decided by characteristics of the solar cell instead of environmental conditions. Usually, $k$ is in the range of $[0.75,0.85]$.

Based on the simulation results of Figure 5, the relationship between solar irradiance $I_{r}, V_{o c}, V_{m p p}$, and $k$ is shown in Table 1 . Subsequently, $k$ is set to be the average value of 0.81 in the following circuit simulation.

Table 1. Results of $V_{o c}, V_{m p p}$, and $k$ under different solar irradiance.

\begin{tabular}{cccc}
\hline $\boldsymbol{I}_{\boldsymbol{r}}\left(\mathbf{W} / \mathbf{m}^{\mathbf{2}}\right)$ & $\boldsymbol{V}_{\boldsymbol{o c}}(\mathbf{V})$ & $\boldsymbol{V}_{\boldsymbol{m p p}}(\mathbf{V})$ & $\boldsymbol{k}$ \\
\hline 1000 & 5.4622 & 4.5111 & 0.8259 \\
800 & 5.3754 & 4.4412 & 0.8262 \\
600 & 5.2632 & 4.2637 & 0.8101 \\
400 & 5.1043 & 4.0762 & 0.7986 \\
200 & 4.8296 & 3.9061 & 0.8088 \\
\hline
\end{tabular}

\section{Circuit Simulation}

Based on the above solar cell model, Figure 6 shows the schematic of an independent unit, consisting of a solar cell, a couple of reverse SPDTs, and a bypass diode. The connection method of these three components is the same as Figure 2. The entire unit had five ports. Ports 1 and 4 were the anode and cathode of this unit, which is for serial connection with other units in the main circuit. Ports 3 and 5 were the open-circuit voltage measurement ports, which were connected to the voltage sensor. Port 2 is the light irradiance input. The two SPDTs were under the control of a common input pulse for the aim of synchronous switch operation. The solar cell was connected with other units when SPDTs were turned to Point 2, or connected with the voltage sensor when SPDTs were turned to Point 3.

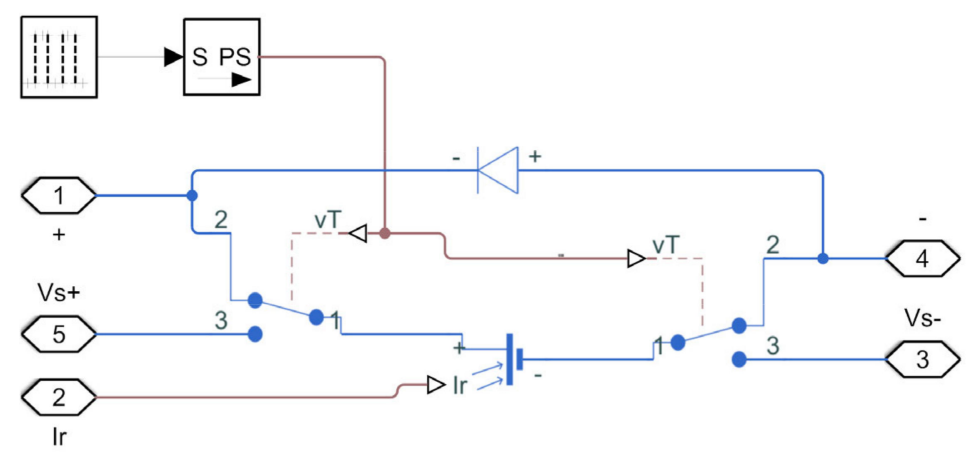

Figure 6. Schematic of an independent unit consisting of one solar cell, one bypass diode and a couple of single pole double throws (SPDTs).

The independent unit in Figure 6 is packaged into a block, and in Figure 7, 110 such blocks are shown. The ports on the encapsulated block correspond to ports in a single unit. Port $1(+)$ and Port 4 $(-)$ in all blocks were connected in series, so that if SPDTs were turned to Point 2, all solar cells cascaded. Port 3 (Vs-) and Port 5 (Vs+) in all blocks were connected in parallel, so that if one couple of SPDTs was turned to Point 3 , the solar cell connected with the SPDTs was shunt with the voltage sensor for MPP calculation. Voltage sensor $U_{o}$ measured the output voltage of the whole system. Voltage sensors $\mathrm{U}_{\mathrm{oc}}$ and $\mathrm{U}_{\mathrm{mpp}}$ measured the open-circuit voltage and MPP voltage of the testing cell, respectively. The resistance value of $R_{0}$ and $R_{1}$ satisfy the expression of $R_{0} /\left(R_{0}+R_{1}\right)=k$, so that open-circuit voltage 
and MPP voltage are in accordance with Equation (8). The measured MPP voltage can be transferred to subsequent DC-DC converters to achieve maximum output power. The ten couples of SPDTs in the blocks are controlled by sequential pulses, so that the solar cells in Blocks 1-10 are consecutively connected to the voltage sensor for open-circuit voltage measuring.

In order to compare the proposed method with the conventional PC method and SPC method, two case studies were applied. One was the time-varying irradiance case, in which all solar cells were subject to the same irradiance varying with time. The other was the spatial-varying irradiance case, in which solar cells were subject to constant but different irradiance according to their respective location.

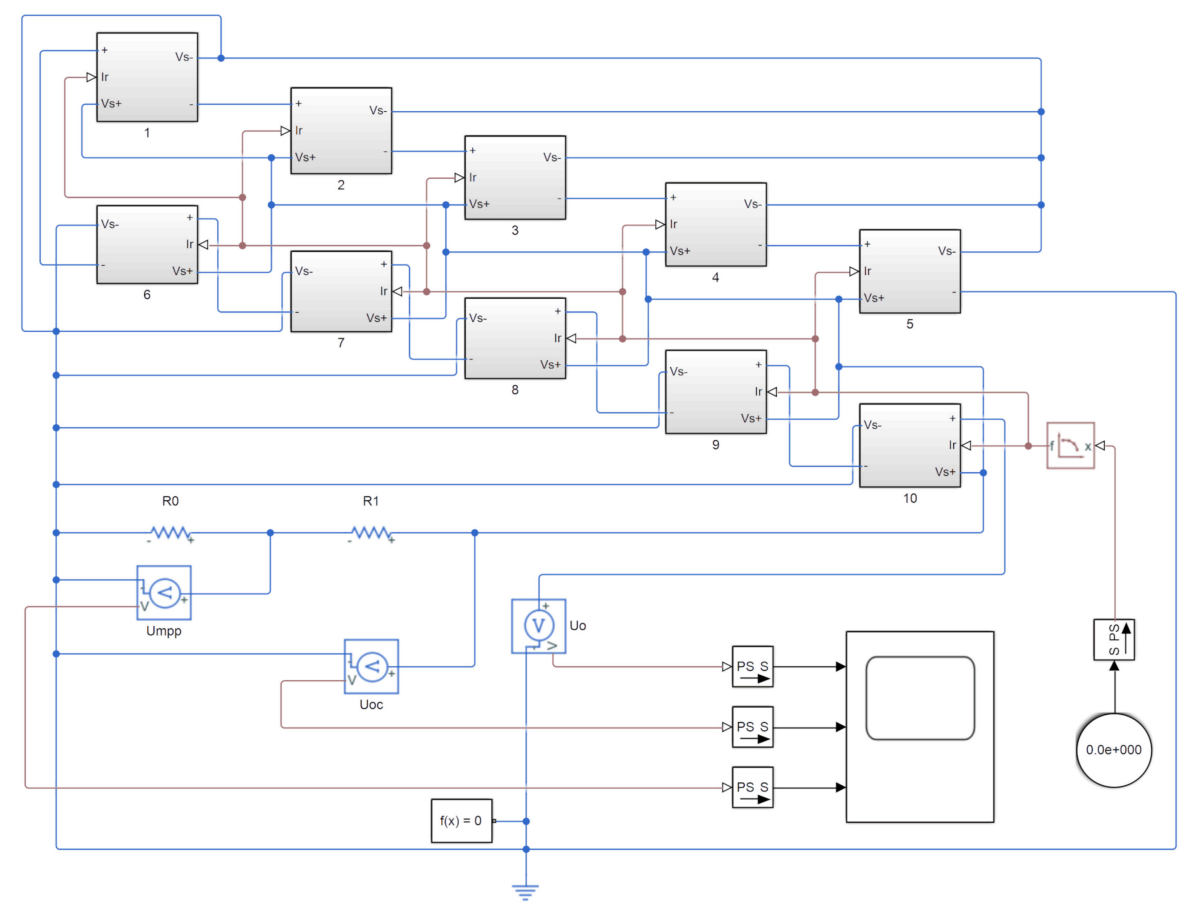

Figure 7. Circuit of the proposed method in MATLAB/Simulink. All ten blocks are the same package of the schematic shown in Figure 6.

In the time-varying irradiance case, Figure 8a shows the typical solar irradiance curve from 0 to $24 \mathrm{~h}$, which is set as the environmental condition. The curve rose above zero after $4 \mathrm{~h}$, reached a maximum of $1000 \mathrm{~W} / \mathrm{m}^{2}$ at $12.27 \mathrm{~h}$, and fell to zero after $20 \mathrm{~h}$. The time period $9-15 \mathrm{~h}$ contained $70.7 \%$ of total solar irradiance, and $11-13 \mathrm{~h}$ contained $40.0 \%$ of total solar irradiance. Thus, the following comparison of simulation results is majorly conducted in these two time periods. Figure $8 \mathrm{~b}$ shows the output voltage of SPC method, the time-varying trend of which is in accordance with that of the solar irradiance curve in Figure 8a. Output voltage was generated between 4-20 h, and the maximum voltage of $6.001 \mathrm{~V}$ was obtained at around $12.27 \mathrm{~h}$. However, due to the repetitive switch in and out of the semi pilot cell, the fluctuation of the output voltage was severe. As is shown in the inset of Figure $8 \mathrm{~b}$, in the time period of $11.52 \mathrm{~h}-11.59 \mathrm{~h}$, a high voltage value corresponding to an output of ten solar cells (semi pilot cell switched in) reached $5.996 \mathrm{~V}$, and the low voltage value corresponding to an output of nine solar cells (semi pilot cell switched out) reacheed $5.396 \mathrm{~V}$. This would result in an increased ripple factor. Due to the slight irradiance increase in the time period shown in the inset of Figure $8 \mathrm{~b}$, both high and low voltages also exhibited the fine increase from $5.994 \mathrm{~V}$ to $5.996 \mathrm{~V}$ and from $5.395 \mathrm{~V}$ to $5.396 \mathrm{~V}$, respectively. The output voltages of the PC method and the proposed method were similar with much fewer ripples, as is shown in Figure 8c. The curves were almost identical because all blocks were subject to the same time-varying irradiance, so that results were similar whether the testing solar cell was fixed or varied. The enlarged curve details in Figure 8c shows that, in the time period of $11.52 \mathrm{~h}-11.59 \mathrm{~h}$, the output voltage of the PC method slightly increased from $5.396 \mathrm{~V}$ to 
$5.397 \mathrm{~V}$, and the output voltage of the proposed method slightly increased from $5.395 \mathrm{~V}$ to $5.396 \mathrm{~V}$. Both rises are in a linear relationship to the solar irradiance value. The reduced ripple effect in both PC and the proposed method is majorly due to the steady number of output solar cells. Theoretically, the ripple factor of the PC method and the proposed method should be the same. However, considering the high-frequency noise induced by switching, the ripple factor of the proposed method is slightly higher than that of the PC method. Obviously, compared with the SPC method, the output power of the PC method and the proposed method were more stable.
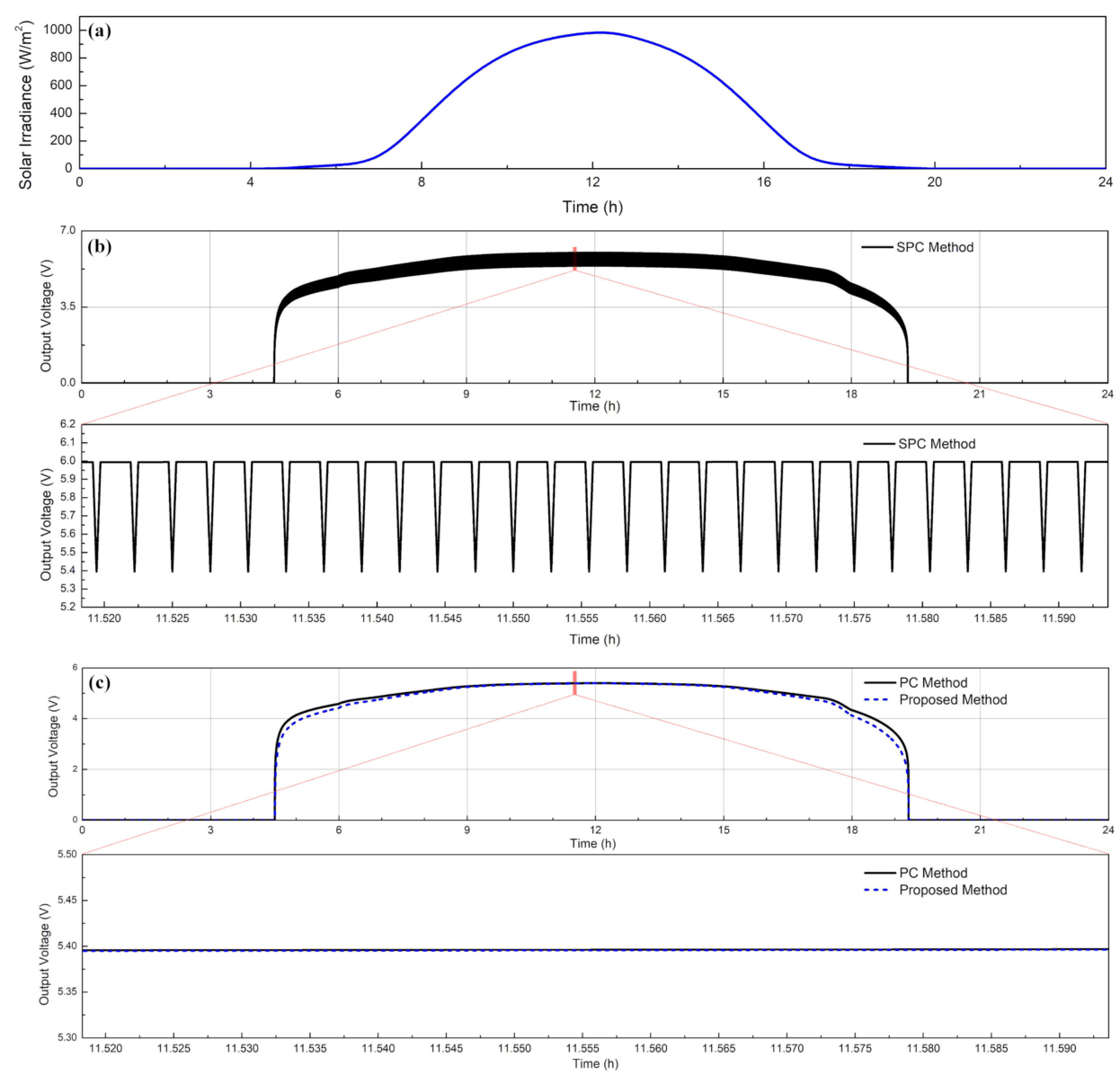

Figure 8. (a) Typical solar irradiance curve, (b) output voltage of the SPC method, and (c) output voltage of the PC method and the proposed method.

The ripple factor of the output voltage is defined as the ratio of the peak-to-peak value of ripple voltage to the absolute value of the DC component. The ripple factors of the PC, SPC, and the proposed method are shown in Table 2. It can be seen that, compared with the SPC method, the ripple factor of the proposed method is decreased by $88.6 \%$ during $11-13 \mathrm{~h}$ and decreased by $53.44 \%$ during $9-15 \mathrm{~h}$. The ripple effect of the proposed method is generally comparable to the PC method. The slight increase is mainly due to the high-frequency noise caused by switching.

Table 2. Ripple factor comparison of three methods.

\begin{tabular}{cccc}
\hline Time Period & PC Method & SPC Method & Proposed Method \\
\hline $11-13 \mathrm{~h}$ & $0.11 \%$ & $1.14 \%$ & $0.13 \%$ \\
$9-15 \mathrm{~h}$ & $0.73 \%$ & $1.89 \%$ & $0.88 \%$ \\
\hline
\end{tabular}

In the spatial-varying irradiance case, nine solar cells were divided into different regions in which the light irradiance radiated from one angle or center symmetrical, as is shown in Figure $9 \mathrm{a}, \mathrm{b}$ 
respectively. The irradiance distribution in Figure 9a is denoted by corner irradiation, while that in Figure $9 \mathrm{~b}$ is denoted by middle irradiation. In both spatial distributions, maximal and minimal light irradiance were controlled to be $1000 \mathrm{~W} / \mathrm{m}^{2}$ and $800 \mathrm{~W} / \mathrm{m}^{2}$. The average light irradiance in both distributions was $925.5 \mathrm{~W} / \mathrm{m}^{2}$. The testing solar cell was denoted by the 10th solar cell, and was under constant light irradiance of $800 \mathrm{~W} / \mathrm{m}^{2}$. In the initial simulation step, i.e., $t=0$, the 10th solar cell was connected with and measured by the voltage sensor to obtain its open-circuit voltage $V_{10, o c}$ and MPP voltage $V_{10, m p p}$. In the PC method, the 10th solar cell was steadily connected with the voltage sensor. In the SPC method, the 10th solar cell was alternatively switched in and out with other solar cells, and MPP calculation took place only when it was switched out. The switching duty cycle was set as $1: 10$. In the proposed method, all ten solar cells were connected to the voltage sensor in the sequence of $10,1,2 \ldots, 9$, repetitively, each exhibiting the duty cycle of 1:10.
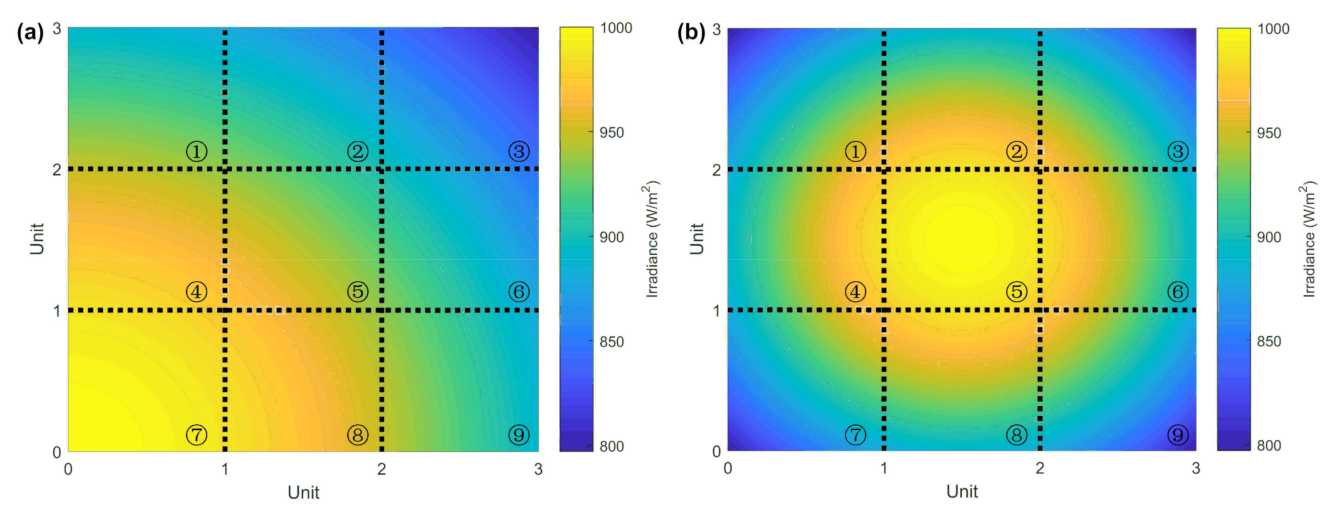

Figure 9. Light irradiance distribution on photovoltaic system with nine solar cells: (a) corner irradiation; (b) middle irradiation.

Figure 10 compares the output voltage of the proposed method with PC and SPC methods. For the PC method, as is shown in Figure 10a, the output voltage of the system was generated by nine solar cells steadily, and thus output voltage curve was a flat line representing $5.38 \mathrm{~V}$. Since the average light irradiance in both corner irradiation and middle irradiation was the same, the difference in the output voltage can be neglected. Figure $10 \mathrm{~b}$ shows the curve of $V_{10, o c}$ and $V_{10, m p p}$ for the tested 10th solar cell. As the 10th solar cell was under constant irradiance of $800 \mathrm{~W} / \mathrm{m}^{2}$, regardless of corner irradiation or middle irradiation, both $V_{10, o c}$ and $V_{10, m p p}$ were identical flat lines in two spatial-varying irradiance cases. For the SPC method, Figure 10c shows the output voltage of all solar cells. Again due to the same average light irradiance, output voltage curves were the same for corner and middle irradiation. Still, output voltage curves fluctuated between $5.96 \mathrm{~V}$ and $5.37 \mathrm{~V}$, corresponding to ten and nine solar cells switched in. In Figure 10d, the voltage curves $V_{10, o c}$ and $V_{10, m p p}$ of the SPC method were characterized by a series of spikes, which were in synchronization with the measurement window phase of the 10th solar cell. Still, both $V_{10, o c}$ and $V_{10, m p p}$ values of the chosen semi pilot cell were constant, which cannot reflect the spatial distribution differences. Figure 10e,f shows the results of the proposed method. It can be seen from Figure 10e that, by consecutively changing the testing solar cell, different spatial distributions of irradiance can be traced, as output voltage curves of corner irradiation and middle irradiation are different. The two insets in Figure 10e show the detailed changing process of output voltage in corner irradiation and middle irradiation, with the numbers indicating the specific solar cell under measurement. The trend of the changing output voltage was in accordance with the light irradiance distribution shown in Figure 9. Figure $10 \mathrm{f}$ shows the $V_{10,0 c}$ and $V_{10, m p p}$ curves of the proposed method. For corner irradiation and middle irradiation, the voltage curves in the two cases were no longer identical, proving the effectiveness of the proposed method in tracing spatially variant irradiance. Since $V_{10, m p p}$ is changing with each solar cell, all solar cells in the photovoltaic system can be set at its MPP. In this way, the optimization of output power can be 
achieved at an arbitrary location, which is suitable to be combined with distributed sensing and applied in smart photovoltaic systems.
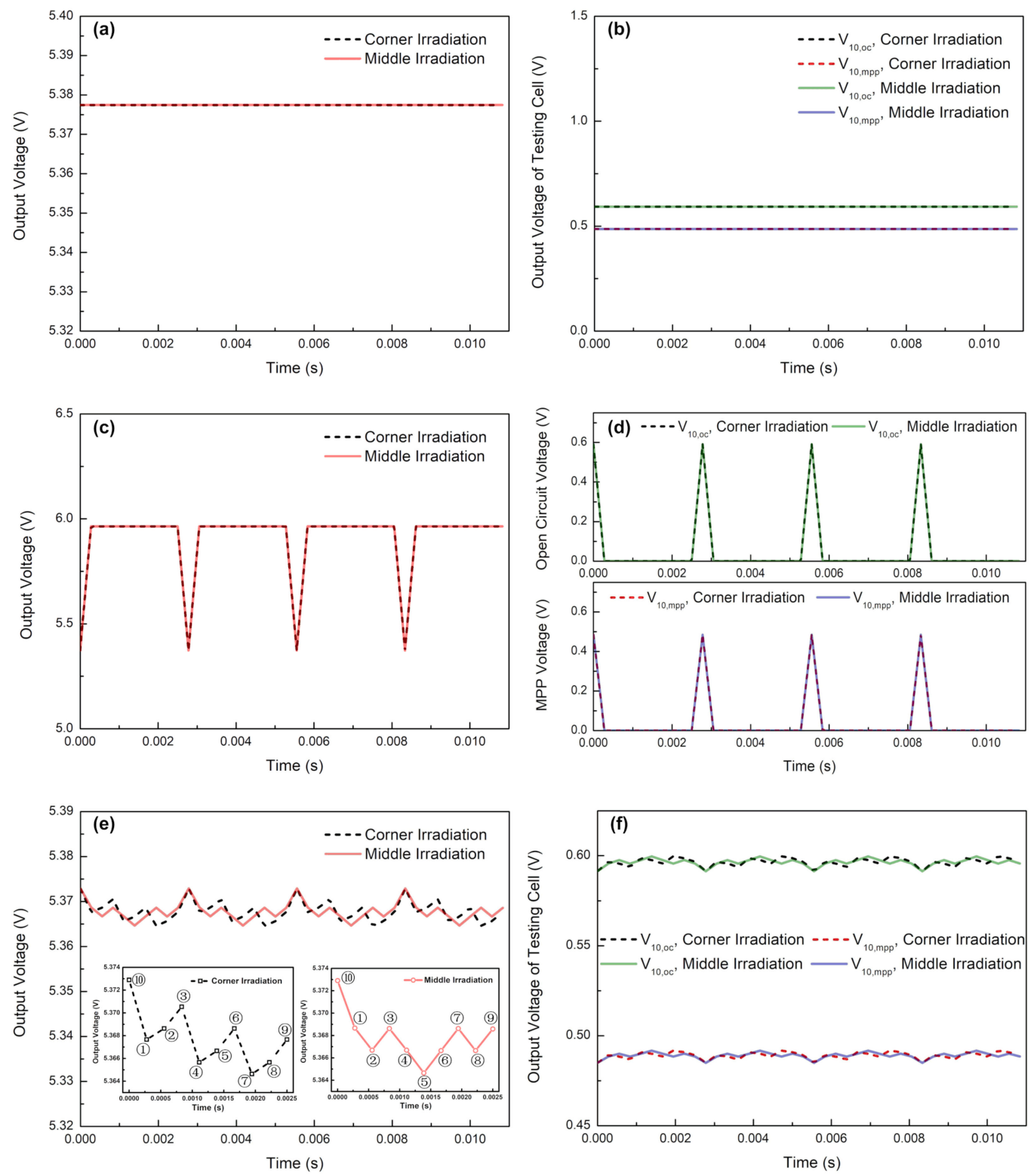

Figure 10. Output voltage in two spatial-varying irradiance cases: $(\mathbf{a}, \mathbf{b})$ PC method; (c,d) SPC method; $(\mathbf{e}, \mathbf{f})$ proposed method. $(\mathbf{a}, \mathbf{c}, \mathbf{e})$ plot the total output voltage, while $(\mathbf{b}, \mathbf{d}, \mathbf{f})$ plot the open-circuit voltage and MPP voltage of the testing cell.

For PC, SPC and the proposed method, Figure 11 compares the obtained MPP voltage with expected MPP voltage in corner irradiation and middle irradiation. The expected MPP voltage is simulated for the nine solar cells with irradiance distributions shown in Figure 9, via sampling output voltage and current under different loads. For both corner and middle irradiation, the expected MPP voltage is $4.413 \mathrm{~V}$. In Figure 11a, the time unit $\Delta t$ represents the measurement window. For PC and SPC method, since the chosen cells are under constant irradiance in both spatial distributions, the chosen cells reflect the constant MPP voltage of $4.375 \mathrm{~V}$ and $4.365 \mathrm{~V}$ after nine time units, respectively. However, for the proposed method, because each solar cell is consecutively measured, the MPP voltage value is continuously updating. After nine time units, all solar cells have been traversed, and the updated MPP voltages of $4.406 \mathrm{~V}$ in both distributions are much closer to the expected MPP voltages, demonstrating 
higher accuracy of $99.85 \%$ compared with the PC method (99.15\%) and SPC method (98.92\%). Figure $11 \mathrm{~b}$ further points out that the deviation to expected MPP voltage is relevant to light irradiance on the testing cell, which is expressed as a percentage to average irradiance on nine solar cells. It can be seen that, for PC and SPC methods, the deviation increases as the percentage increases or decreases. Only when light irradiance on the testing cell equals average irradiance, the deviation can be controlled below $0.14 \%$. When the percentage reduces to $64.8 \%$ or increases to $135.1 \%$, the deviation can be up to $-2.93 \%$ and $1.81 \%$, respectively. While for the proposed method, the deviation is controlled to be less than $0.15 \%$ regardless of the testing cell irradiance percentage, which again proves the effectiveness of the proposed method in situations with spatially varying irradiance.
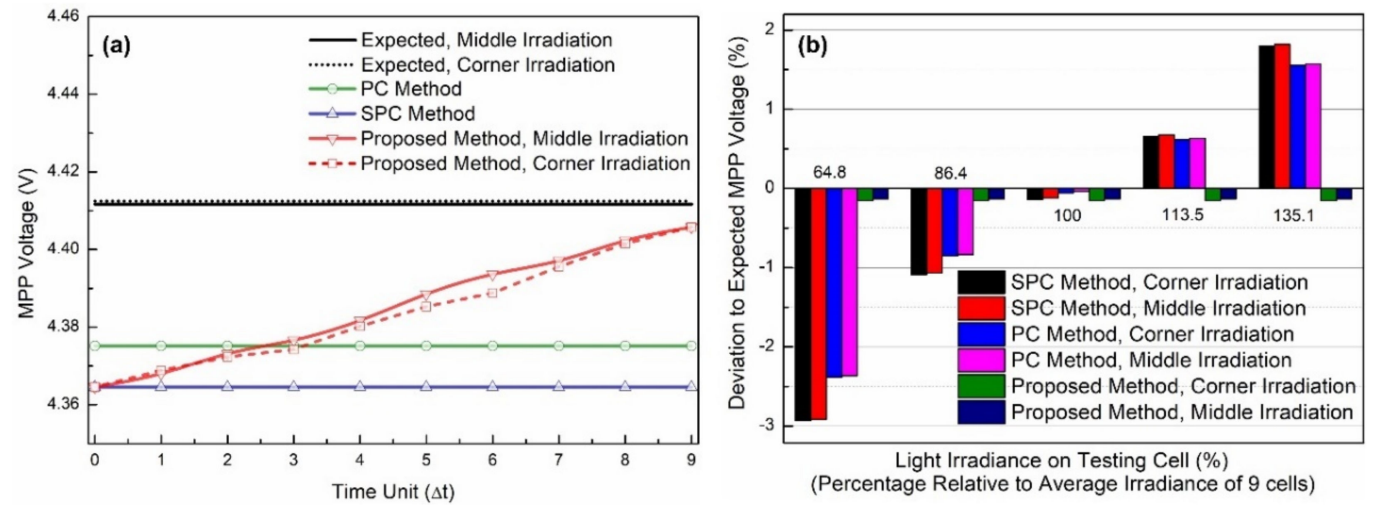

Figure 11. (a) Variation of MPP voltages obtained in nine time units by PC, SPC, and the proposed methods in middle irradiation and corner irradiation. (b) Deviation to expected MPP voltages after nine time units by PC, SPC, and the proposed methods in middle irradiation and corner irradiation.

\section{Experiment}

Experimental verification of the proposed on-site traversal FOCV method was conducted on the solar panel scale. The output characteristics of the ten solar panels $(6 \mathrm{~W})$ were: $\operatorname{Voc}=7.2 \pm$ $0.2 \mathrm{~V}$, Isc $=1.1 \pm 0.1 \mathrm{~A}$. The ten pairs of SPDTs were realized by five integrated analog switch chips MAX394EPP, each with two pairs of SPDTs. The micro-controller STC90C516RD+ is selected as the controlled pulse generator. The pulse width was set to be $200 \mathrm{~ms}$, i.e., the measurement time window for each solar panel was $200 \mathrm{~ms}$, and one cycle of system operation was $2 \mathrm{~s}$. The control strategy was based on the precision timing of the crystal oscillator, so that interrupt service routine was called every $200 \mathrm{~ms}$ to alter the voltage level of analog switch input. The ten pairs of SPDTs were thus switched on and off consecutively. The output voltage of nine solar panels in series $V_{\text {out }}$ was recorded on an oscilloscope. Figure 12 shows the photo of the experimental system, including ten solar panels, SPDT switch circuitry integrated on printed circuit board, micro-controller and oscilloscope, as well as a DC power supply for powering analog switches and the micro-controller.

During the test, the light irradiance of the ten solar panels was controlled to be around $785 \mathrm{~W} / \mathrm{m}^{2}$. Figure 13 shows the testing results under constant light irradiance. In Figure 13a, $V_{\text {out }}$ reaches $50.4 \mathrm{~V}$ and its waveform is generally stable. During the $2 \mathrm{~s}$ system cycle, both $V_{10, o c}$ and $V_{10, m p p}$ experiencd slight changes due to non-uniform light irradiance distribution on all solar panels. The fluctuations of the $V_{10, o c}$ and $V_{10, m p p}$ curves also demonstrated that the diverse output performance of each solar panel can be effectively traced by the proposed method. The average value of $V_{10, o c}$ was approximately $4.76 \mathrm{~V}$, and the average value of $V_{10, m p p}$ is $3.85 \mathrm{~V}$. The output voltage curves in 20 system cycles have also been tested. As is shown in Figure 13b, both $V_{10, o c}$ and $V_{10, m p p}$ exhibit clear periodicity, while $V_{\text {out }}$ remains generally stable throughout $40 \mathrm{~s}$. The periodicity of $V_{10, o c}$ and $V_{10, m p p}$ is in accordance with fluctuations within one system cycle. The ripple factor of $\mathrm{V}_{\text {out }}$ is $1.55 \%$, which is mainly due to switch operations. The obtained MPP voltage can be further transferred to DC-DC converter to adjust load capacity to achieve maximum output power and to enhance conversion efficiency under real environmental 
conditions. Since the experimental fluctuations of $V_{10, o c}$ and $V_{10, m p p}$ curves reflect the non-uniform performance of all solar panels, it is expected that the proposed method is applicable both in constant irradiance and in time-varying or spatial-varying irradiance environment.

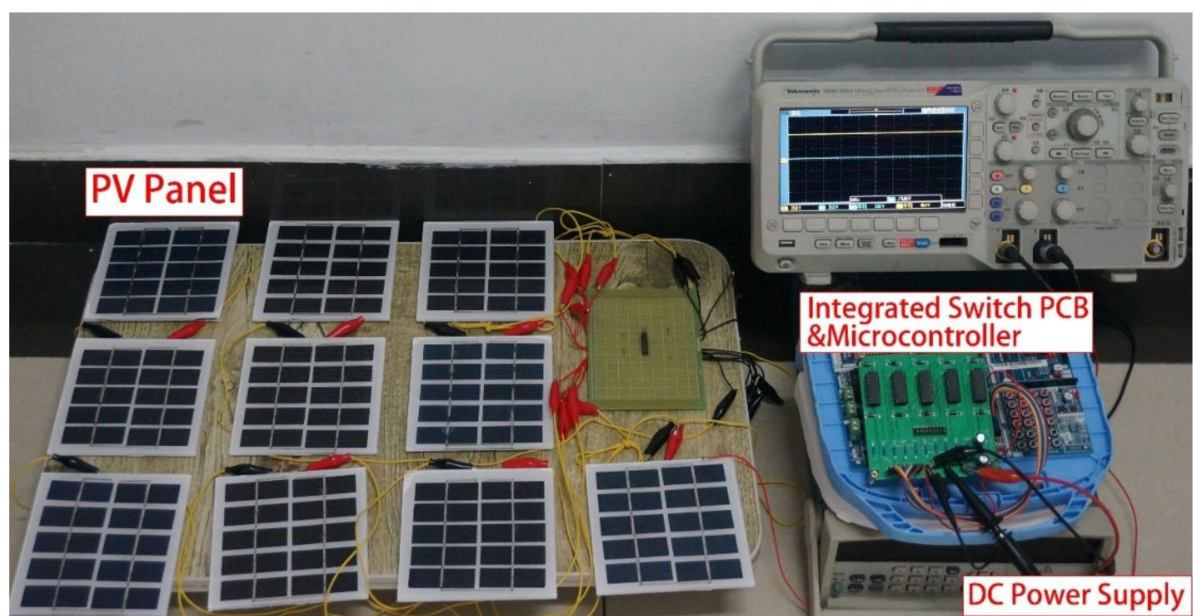

Figure 12. Photo of the experimental system.
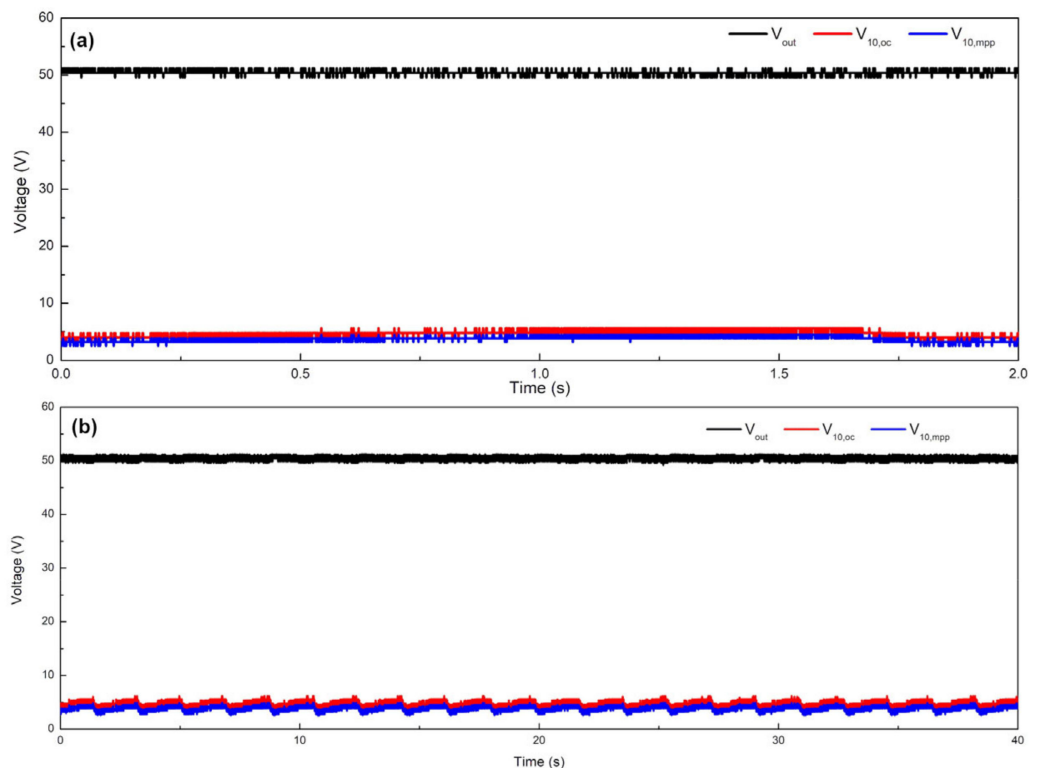

Figure 13. Experiment results: (a) output voltage curves within one system cycle, (b) output voltage curves within twenty system cycles.

\section{Discussion}

The proposed method offers the possibility to combine with distributed sensing by locating and controlling specific solar cells or solar panels. As the size and cost of switching elements and control units on circuit boards are continuously decreasing, it is expected that the cost of the proposed method can be contained at a relatively low level. Integration and packaging technologies such as the Package-on-Package (PoP) will also help to reduce the cost for on-chip realization. The endurance of the electronic switches has been significantly improved over the years, so that the reliability of the system will be enhanced to match the lifetime of the solar cells or solar panels.

Despite the efficiency loss arising from the fact that the output voltage of one unit is not connected to the load for purpose of measurement, it is expected that the dual advantages of enhanced MPP accuracy and reduced ripple factor outweigh such efficiency loss. Moreover, for large scale photovoltaic systems with more than 100 units, the efficiency loss can be diluted to approximately $1 \%$. In the distributed 
sensing configuration, the number of units can be even higher due to the exclusion of laying restrictions, which renders the efficiency loss negligible.

The installation complexity of the proposed method is relatively low. As can be seen from Figures 6 and 7 , all units are connected using the same schematic, so that required circuits take

The form of blocks of the unit circuit and the connection can be achieved by a plug-in through corresponding pins on the solar unit and the required circuits. The installation complexity can be further reduced if the unit circuit is integrated on-chip for solar cells or solar panels.

The chief advantage of the proposed method is the ability to measure FOCV and calculate MPP based on specific solar cells or solar panels, which offers the possibility of novel MPPT configuration through combination with distributed sensing. Based on this, future works can be carried out concerning remote control strategies, traverse conditions, and environmental limit conditions, etc. These future works will incorporate distributed sensing into optimizing MPP algorithms, which is conducive to enhancing efficiency and simplifying management for smart photovoltaic systems.

\section{Conclusions}

A novel on-site traversal FOCV MPPT method with uninterrupted output power is presented in this paper. As each solar cell is in connection with a bypass diode and a pair of SPDTs, a specific solar cell can be connected either in series with other solar cells for power generation or parallel to a voltage sensor for open-circuit voltage measuring. By controlling the SPDTs, all solar cells can be measured consecutively for determining MPP. In MATLAB/Simulink simulation, the proposed method achieves a low ripple factor of $0.13 \%$ in $11-13 \mathrm{~h}$ and $0.88 \%$ in $9-15 \mathrm{~h}$ in the time-varying irradiance case. In the spatial-varying irradiance case, the proposed method achieves an MPP accuracy of $99.85 \%$. Both simulation and experimental results show that, the proposed method is effective to trace spatially varying irradiance and diverse output characteristics of all solar cells, with high MPP accuracy and a limited ripple effect. Using the proposed method, the experimental output voltage of ten solar cells are stable, the ripple factor of which is $1.55 \%$. These results demonstrate that the proposed method is suitable to be combined with distributed sensing for future applications in smart photovoltaic systems.

Author Contributions: Conceptualization, L.B. and S.Q.; methodology, L.B. and S.Q.; validation, S.Q., J.H. and F.L.; formal analysis, L.B., J.H, F.L. and Q.L.; investigation, L.B., J.H., F.L. and Q.L.; writing—original draft preparation, L.B.; writing-review and editing, L.B., F.L., Q.L. and X.W.; visualization, S.Q.; supervision, L.B.; project administration, L.B.; funding acquisition, L.B. and X.W. All authors have read and agreed to the published version of the manuscript.

Funding: This research was funded by Key Projects of the National Natural Science Foundation of China, grant number 61834003.

Acknowledgments: Authors would like to thank Bingji Xu and Huiyong Xu from China University of Geosciences Beijing for in-depth discussions.

Conflicts of Interest: The authors declare no conflict of interest.

\section{References}

1. IRENA. Renewable Capacity Statistics 2020; International Renewable Energy Agency (IRENA): Abu Dhabi, UAE, 2020; ISBN 978-92-9260-239-0.

2. NEA. The Increase in the Installed Capacity of Solar Power Reached 53.06 MW; National Energy Administration: Beijing, China, 2018. Available online: http://www.nea.gov.cn/2018-01/24/c_136920159.htm (accessed on 12 July 2020).

3. NREC. China 2050 High Renewable Energy Penetration Scenario and Roadmap Study; Energy Research Institute: Beijing, China, 2015; Available online: http://www.efchina.org/Attachments/Report/report-20150420/ China-2050-High-Renewable-Energy-Penetration-Scenario-andRoadmap-Study-Executive-Summary.pdf (accessed on 6 May 2020). 
4. Bharath, K.R.; Suresh, E. Design and implementation of improved fractional open circuit voltage based maximum power point tracking algorithm for photovoltaic applications. Int. J. Energy Res. 2017, 7, 1108-1113.

5. Pathak, P.K.; Yadav, A.K. Design of battery charging circuit through intelligent MPPT using SPV system. Sol. Energy 2019, 178, 79-89. [CrossRef]

6. Dhimish, M. Assessing MPPT techniques on hot-spotted and partially shaded photovoltaic modules: Comprehensive review based on experimental data. IEEE Trans. Power Electr. 2019, 66, 1132-1144. [CrossRef]

7. Tey, K.S.; Mekhilef, S. Modified incremental conductance algorithm for photovoltaic system under partial shading conditions and load variation. IEEE Trans. Power Electr. 2014, 61, 5384-5392.

8. Soon, T.K.; Mekhilef, S. A fast converging MPPT technique for photovoltaic system under fast varying solar irradiation and load resistance. IEEE Trans. Ind. Inform. 2015, 11, 176-186. [CrossRef]

9. Koutroulis, E.; Sason, N.; Georgiadis, V. Combined tracking of the maximum power and maximum efficiency operating points for real-time maximization of the energy production of PV systems. IEEE Trans. Power Electr. 2019, 34, 8634-8645. [CrossRef]

10. Yang, B.; Zhu, T.; Wang, J.; Shu, H.; Yu, T.; Zhang, X.; Yao, W.; Sun, L. Comprehensive overview of maximum power point tracking algorithms of PV systems under partial shading condition. J. Clean Prod. 2020, 268, 121983. [CrossRef]

11. Tafti, H.D.; Konstantinou, G.; Townsend, C.D.; Farivar, G.G.; Sangwonwanich, A.; Yang, Y.; Pou, J.; Blaabjerg, F. Extended functionalities of photovoltaic systems with flexible power point tracking: Recent advances. IEEE Trans. Power Electr. 2020, 35, 9342-9356. [CrossRef]

12. Sundareswaran, K.; Vigneshkumar, V.; Sankar, P.; Simon, S.P.; Nayak, P.S.R.; Palani, S. Development of an improved $\mathrm{P} \& \mathrm{O}$ algorithm assisted through a colony of foraging ants for MPPT in PV System. IEEE Trans. Ind. Inform. 2016, 12, 187-200.

13. Bayrak, F.; Ertürk, G.; Oztop, H.F. Effects of partial shading on energy and exergy efficiencies for photovoltaic panels. J. Clean. Prod. 2017, 164, 58-69. [CrossRef]

14. Rawy, K.; Kalathiparambil, F.; Maurath, D.; Kim, T.T.H. A selfadaptive time-based mppt with $96.2 \%$ tracking efficiency and a wide tracking range of $10 \mu \mathrm{A}$ to $1 \mathrm{~mA}$ for IoT applications. IEEE Trans. Circuits Syst. I 2017, 64, 2334-2345. [CrossRef]

15. Loukriz, A.; Haddadi, M.; Messalti, S. Simulation and experimental design of a new advanced variable step size Incremental Conductance MPPT algorithm for PV systems. ISA Trans. 2016, 62, 30-38. [CrossRef]

16. Hosseini, S.; Taheri, S.; Farzaneh, M.; Taheri, H. A high performance shade-tolerant MPPT based on current-mode control. IEEE Trans. Power Electr. 2019, 34, 10327-10340. [CrossRef]

17. Rai, A.K.; Kaushika, N.D.; Singh, B.; Agarwal, N. Simulation model of ANN based maximum power point tracking controller for solar PV system. Sol. Energy Mater. Sol. Cells 2011, 95, 773-778. [CrossRef]

18. Singh, M.D.; Shine, V.J.; Janamala, V. Application of artificial neural networks in optimizing MPPT control for standalone solar PV system. In Proceedings of the International Conference on Contemporary Computing and Informatics 2014, Mysore, India, 27-29 November 2014; pp. 162-166.

19. Kulaksiz, A.A.; Akkaya, R. A genetic algorithm optimized ANNbased MPPT algorithm for a stand-alone PV system with induction motor drive. Sol. Energy 2012, 86, 2366-2375. [CrossRef]

20. Husain, M.A.; Tariq, A.; Hameed, S.; Arif, M.; Jain, A. Comparative assessment of maximum power point tracking procedures for photovoltaic systems. Green Energy Environ. 2017, 2, 5-17. [CrossRef]

21. Almonacid, F.; Fernandez, E.F.; Rodrigo, P.; Perez-Higueras, P.J.; Rus-Casas, C. Estimating the maximum power of a High Concentrator Photovoltaic (HCPV) module using an Artificial Neural Network. Energy 2013, 53, 165-172. [CrossRef]

22. Chen, Y.T.; Jhang, Y.C.; Liang, R.H. A fuzzy-logic based autoscaling variable step-size MPPT method for PV systems. Sol. Energy 2016, 126, 53-63. [CrossRef]

23. Manimekalai, P.; Kumar, R.H.; Raghavan, S. Enhancement of fuzzy controlled photovoltaic-diesel system with battery storage using interleaved converter with hybrid MPPT for rural home. J. Sol. Energy Eng. 2015, 137, 061005. [CrossRef]

24. Priyadarshi, N.; Padmanaban, S.; Sagar, B.M.; Blaabjerg, F.; Sharma, A. Fuzzy SVPWM-based inverter control realisation of grid integrated photovoltaic-wind system with fuzzy particle swarm optimisation maximum power point tracking algorithm for a grid-connected PV/wind power generation system: Hardware implementation. IET Electr. Power Appl. 2018, 12, 962-971. [CrossRef] 
25. Mohanty, S.; Subudhi, B.; Ray, P.K. A Grey Wolf-Assisted Perturb \& Observe MPPT Algorithm for a PV System. IEEE Trans. Energy Conver. 2017, 32, 340-347.

26. Sundareswaran, K.; Sankar, P.; Nayak, P.S.R. Enhanced energy output from a PV system under partial shaded conditions through artificial bee colony. IEEE Trans. Sustain. Energy 2015, 6, 198-209. [CrossRef]

27. Gopalakrishnan, S.K.; Kinattingal, S.; Simon, S.P.; Kumar, K.A. Enhanced energy harvesting from shaded PV systems using an improved particle swarm optimization. IET Renew Power Gen. 2020, 14, 1471-1480. [CrossRef]

28. Priyadarshi, N.; Padmanaban, S.; Holm-Nielsen, J.B.; Blaabjerg, F.; Bhaskar, M.S. An experimental estimation of hybrid ANFIS-PSO-based MPPT for PV grid integration under fluctuating sun irradiance. IEEE Syst. J. 2019, 14, 1-12. [CrossRef]

29. Priyadarshi, N.; Padmanaban, S.; Holm-Nielsen, J.B.; Bhaskar, M.S.; Azam, F. Internet of Things augmented a novel PSO-employed modified zeta converter-based photovoltaic maximum power tracking system: Hardware realisation. IET Power Electron. 2020, 13, 2775-2781. [CrossRef]

30. Yang, H.; Yue, G.; Kang, L. Multi-peak MPPT Control Based on PSO and INC Algorithms. J. Power Supply 2019, 17, 128-136.

31. Harrag, A.; Messalti, S. How fuzzy logic can improve PEM fuel cell MPPT performances? Int. Trans. J. Hydrog. Energy 2018, 43, 537-550. [CrossRef]

32. Motahhir, S.; Hammoumi, A.E.; Ghzizal, A.E. The most used MPPT algorithms: Review and the suitable low-cost embedded board for each algorithm. J. Clean Prod. 2020, 246, 118983. [CrossRef]

33. Huang, Y.P. A rapid maximum power measurement system for high-concentration photovoltaic module using the fractional open-circuit voltage technique. IEEE J. Photovol. 2014, 4, 1610-1617. [CrossRef]

34. Li, S.; Ping, A.; Liu, Y.; Ma, X.; Li, C.A. variable-weather-parameter MPPT method based on a defined characteristic resistance of photovoltaic cell. Sol. Energy 2020, 199, 673-684. [CrossRef]

35. Hsu, T.W.; Wu, H.H.; Tsai, D.L.; Wei, C.L. Photovoltaic energy harvester with fractional open-circuit voltage based maximum power point tracking circuit. IEEE Trans. Circuits Syst. II 2019, 66, 257-261. [CrossRef]

36. Omairi, A.; Ismail, Z.H.; Danapalasingam, K.A.; Ibrahim, M. Power harvesting in wireless sensor networks and its adaptation with maximum power point tracking: Current technology and future directions. IEEE Internet Things 2017, 4, 2104-2115. [CrossRef]

37. Baimel, D.; Tapuchi, S.; Levron, Y.; Belikov, J. Improved fractional open circuit voltage MPPT methods for PV systems. Electronics 2019, 8, 321. [CrossRef]

38. Nadeem, A.; Sher, H.A.; Murtaza, A.F. Online fractional open-circuit voltage maximum output power algorithm for photovoltaic modules. IET Renew. Power Gener. 2020, 14, 188-198. [CrossRef]

Publisher's Note: MDPI stays neutral with regard to jurisdictional claims in published maps and institutional affiliations.

(C) 2020 by the authors. Licensee MDPI, Basel, Switzerland. This article is an open access article distributed under the terms and conditions of the Creative Commons Attribution (CC BY) license (http://creativecommons.org/licenses/by/4.0/). 